\title{
FEATURES OF STRATEGIC MANAGEMENT IN THE DIGITAL ECONOMY
}

\author{
Olga Kryzhanovskaya ${ }^{1}$, ORCID: 0000-0003-0763-2214, \\ Vladimir Plotnikov², ORCID: 0000-0002-3784-6195, \\ Yulia Vertakova ${ }^{3 *}$, ORCID: 0000-0002-1685-2625 \\ ${ }^{1}$ Southwest State University, 305040, st. 50 years of October, 94, Kursk, Russian Federation \\ ${ }^{2}$ St. Peresburg State University of Economics, 194354, st. Sadovaya, 21, St. Peresburg, Russian Federation \\ ${ }^{3}$ Kursk branch of the Financial University under the Government of the Russian Federation, 305016, \\ st. Lomonosov, 3, Kursk, Russian Federation \\ *Corresponding author: Yulia Vertakova, vertakova7@yandex.ru
}

Received: 09. 15. 2021

Accepted: 11. 05. 2021

\begin{abstract}
The article substantiates the relevance of strategic management of organizations in the digital economy, taking into account the specifics of the industry. The development of info communication technologies is currently one of the strategic directions for modernizing the economy not only in Russia, but also in all countries of the world in the context of digital transformation. In connection with the above, the ranking of countries by the Digitalization Index in 2020 has been studied, and the leading countries / markets of the world by the number of smartphone users in 2021 are presented. To improve the strategic management of organizations in the context of digitalization of economies, the key characteristics of internal and external strategic balance are shown, a model of strategic management of organizations - telecom operators is built
\end{abstract}

Keywords: strategy, strategic management, digitalization, digital transformation.

Rezumat. Articolul fundamentează relevanța managementului strategic al organizațiilor în economia digitală, ținând cont de specificul industriei. Dezvoltarea tehnologiilor de informare și comunicații este în prezent una dintre direcțiile strategice pentru modernizarea economiei nu numai în Rusia, ci și în toate țările lumii în contextul transformării digitale. În legătură cu cele de mai sus, a fost studiat clasamentul țărilor după Indexul de digitalizare în 2020 și sunt prezentate țările/piețele lider ale lumii după numărul de utilizatori de smartphone în 2021. Pentru a îmbunătăți managementul strategic al organizațiilor în contextul digitalizării economiilor, sunt prezentate caracteristicile cheie ale echilibrului strategic intern și extern, se construiește un model de management strategic al organizațiilor - operatori de telecomunicații.

Cuvinte cheie: strategie, management strategic, digitalizare, transformare digitală.

\section{Introduction}

The current crisis of economic development has revealed the current directions of the organization's development, having determined the process of optimizing the activities of enterprises in all areas of business as a priority. In conditions of an unstable external 
environment, limited resources, instability of the organization's position in the industry and in the market as a whole, it is important to ensure strategic balance based on the competent use of strategic management tools. Optimization of the organization's management through flexible regulation, timely changes that meet the challenge from the environment, allows not only to achieve competitive advantages, but also to survive, develop in the long term based on achieving a balance between the micro and macro business environment, ensuring strategic balance. At the same time, it is necessary to take into account the specifics of the industry's development, which will help to select the most effective strategic management tools. Research by foreign scientists in the field of strategic management (Ackoff R., Albert M., Ansoff I., Chandler D., David R., Drucker F., Fayol H., Kotler F., Mescon H., Khedouri F., Mintzberg H., Porter M., Thompson A., Gamble J., Strickland A. [1 - 11] and others) indicate the relevance of modern research in the field of strategic management. The study of issues of strategic planning and management in industries and spheres of business always gains high weight in the context of an unstable external environment. However, theoretical and methodological issues of ensuring the strategic balance of telecom operators require a more thorough scientific study, which made it possible to formulate the goal and objectives of the dissertation research.

Even though such representatives of the scientific community as Vertakova Y., Kryzhanovskaya O., Plotnikov V., Leontyev E. [12 - 14] and others were engaged in the issues of strategic management in the industry of information and communications of the Russian Federation, the issues of strategic optimization of the business of telecom operators to ensure strategic balance require further scientific research. elaboration.

Thus, the analysis of the strategic development of domestic and foreign telecom operators in the context of digital transformation actualizes the need for scientific research of the theory and practice of strategic planning and the search for new approaches to it, including optimization of the management of organizations - telecom operators - to ensure strategic balance.

\section{Results and Discussion}

The ongoing international studies indicate a close connection between the development of info communication technologies and the economic well-being of the state. The large-scale deployment of high-speed communication technologies and Internet access is a catalyst for the development of ICT projects, creates a multiple multiplier effect on other sectors of the national economy, contributes to the acceleration and scaling of technological progress, which ultimately ensures GDP growth in both individual regions and the country as a whole. In addition, developing countries with better telecommunications infrastructure are attracting more outsourcing companies and foreign investment.

The development of info communication technologies is currently one of the strategic directions for modernizing the economy not only in Russia, but also in all countries of the world in the context of digital transformation.

The report "Digital-enabling countries proved more resilient to the Covid-19 economic shock" presents the leading countries in the Digitalization Index in 2020. Figure 1 shows the top 10 leading countries in this index in 2020 and estimates of the main components index.

The US, Denmark and Germany once again make the top three of our 2020 Enabling Digitalization Index (based on data from end-2019). The EDI measures the ability - and agility - of countries to help digital companies thrive and traditional businesses harness the digital dividend. 


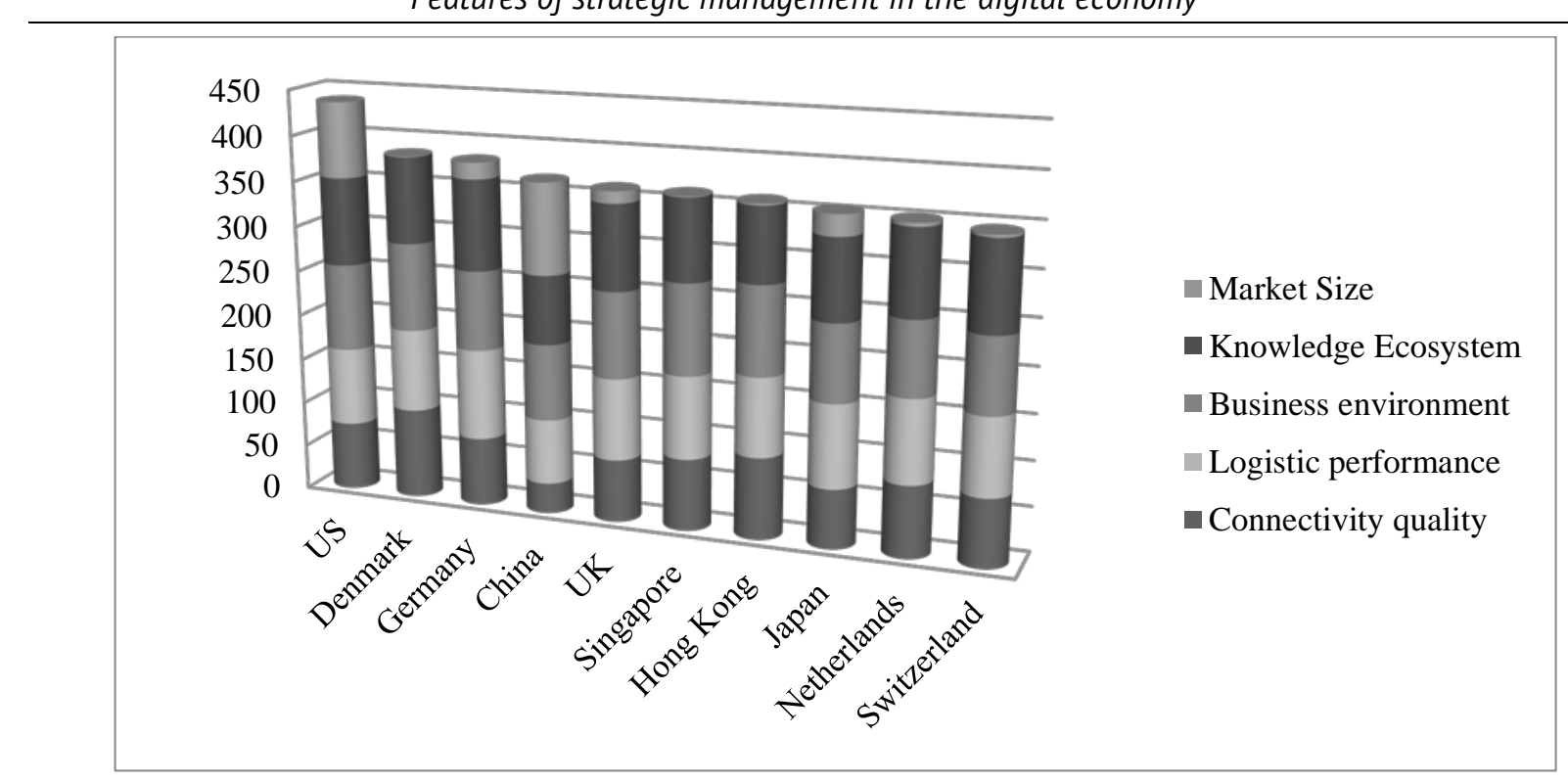

Figure 1. Top 10 Countries in EDI 2020. Source [15].

Russia ranked 38th in the 2020 Digitalization Index ranking, losing one position compared to 2019. Figure 2 shows the estimates of the Digitalization Index components for Russia in 2020.

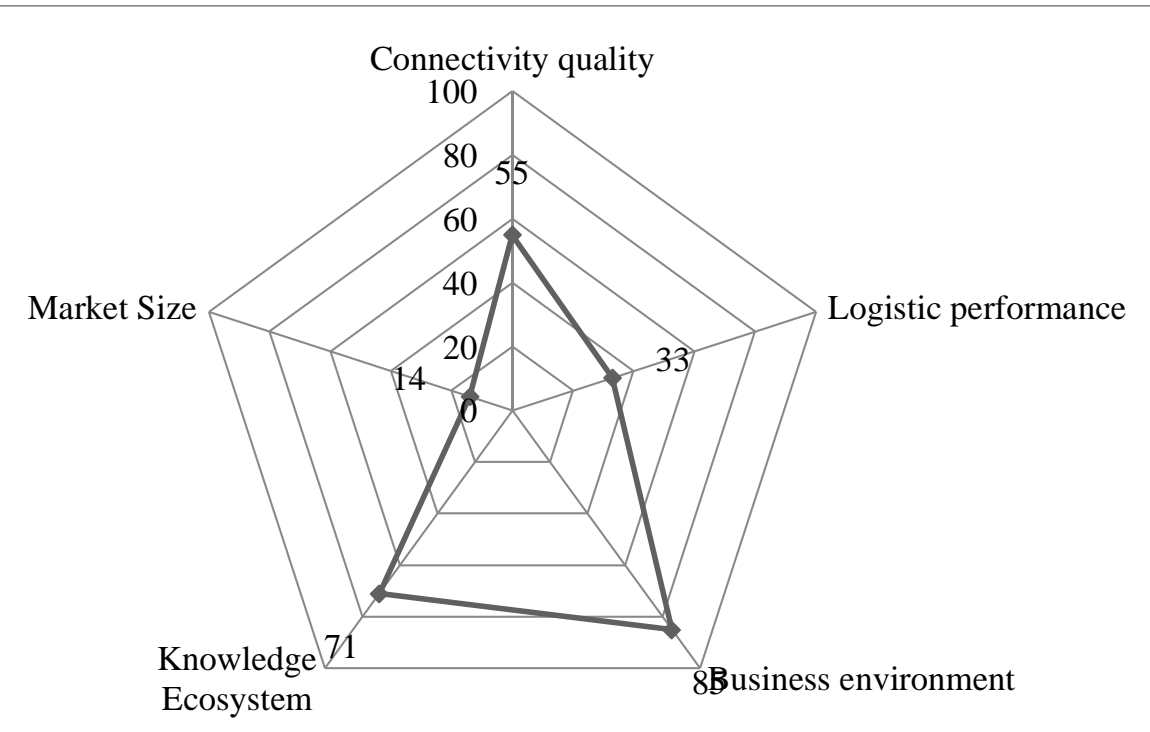

Figure 2. The estimates of the Digitalization Index components for Russia in 2020. Source [15].

In the context of digitalization in the environment of telecom operators, the competition is especially aggravated.

The picture below shows key data points, including population, online population, smartphone users, active smartphones for the top 10 countries/ markets worldwide by number of smartphone users in 2021.

Thus, the problem of optimizing the management of an organization to ensure strategic balance (using the example of telecom operators) in the context of digitalization is becoming increasingly important. 


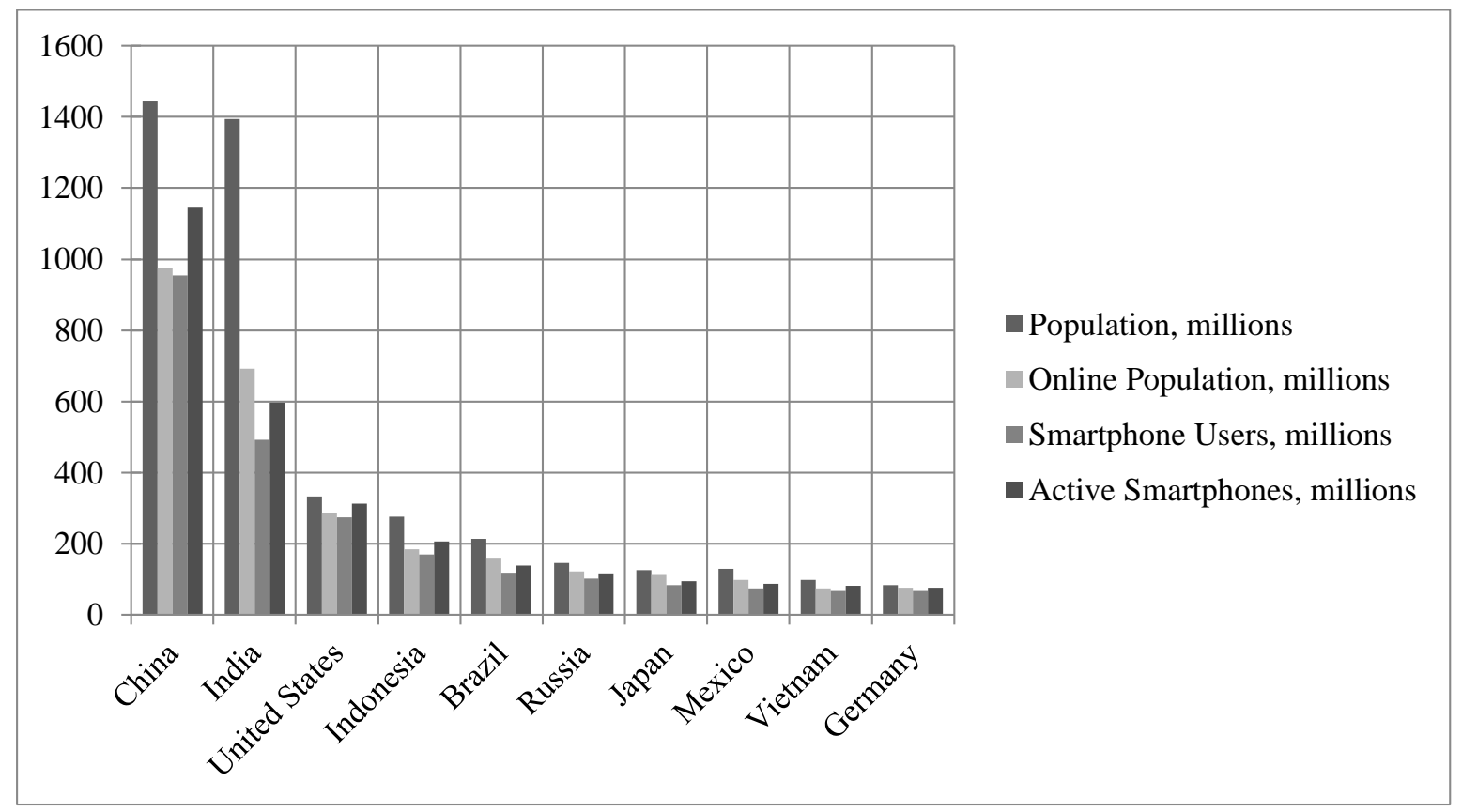

Figure 3. Key data points for the top 10 countries/ markets worldwide by number of smartphone users in 2021.

Source [16].

The picture below shows smartphone penetration for the top 10 countries/markets worldwide by number of smartphone users in 2021.

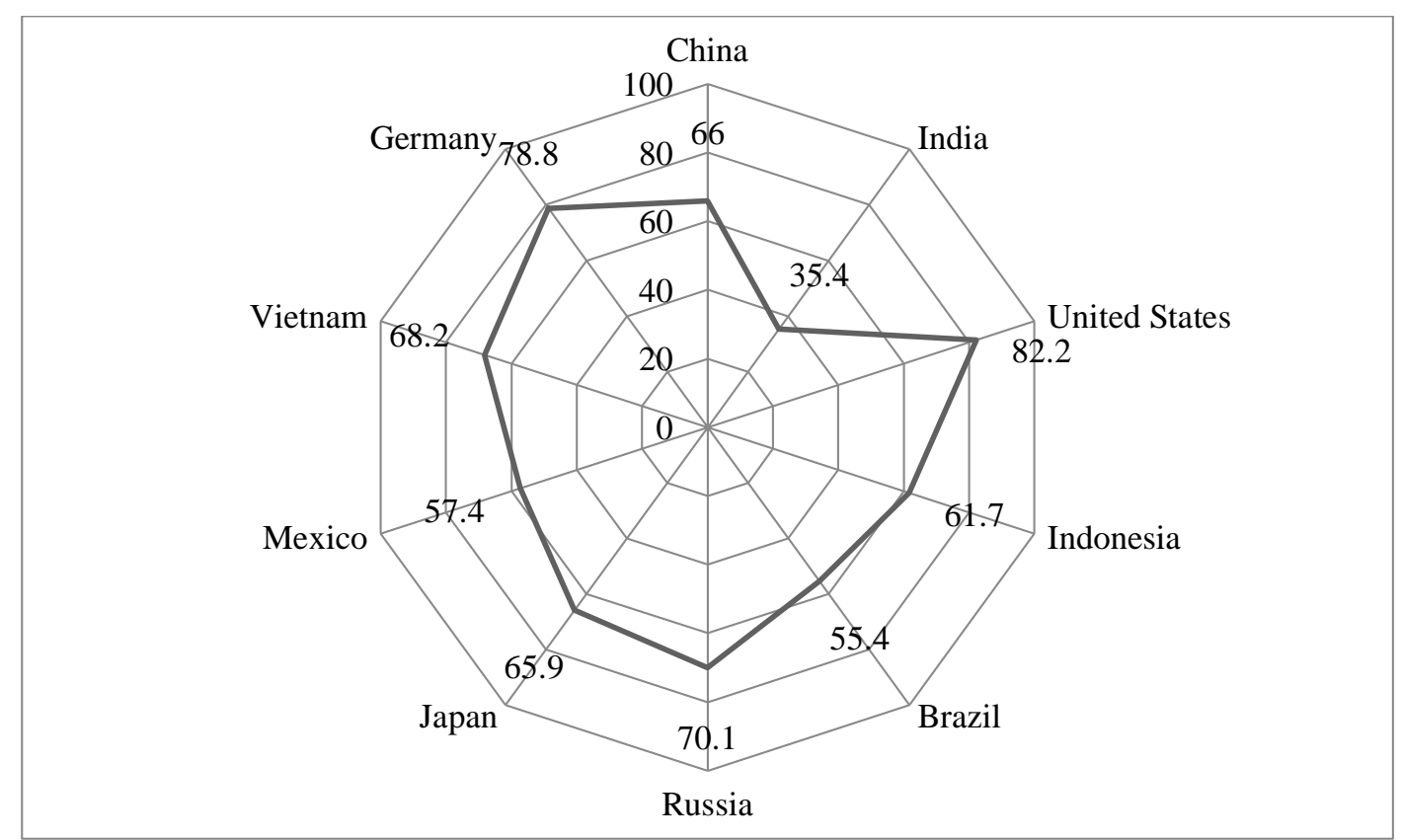

Figure 4. Smartphone penetration for the top 10 countries/ markets worldwide by number of smartphone users in 2021.

Source [16]

In an unstable external environment, organizations have to adapt, change, maneuver to ensure sustainable development, that is, to achieve balance both within the enterprise and in the external environment for a certain period of time.

Organizations are focused on development in the medium or long term, maintaining their key positions in the short term can be interpreted as functioning, "keeping afloat", which is not advisable from the point of view of doing business. That is why the problem of strategic 
balance is becoming urgent.

Based on the conducted research of scientific approaches, it can be argued that there is no generally accepted definition of the strategic equilibrium of an organization. The sources consider only related concepts.

Focusing on the understanding of balance in various areas of research (economics, technology, psychology, physiology, philosophy, statistics, mathematics), we identified the meaningful characteristics of the concept of internal strategic balance of an organization, since it should be considered in two aspects:

- strategic balance as a balance of goals, tasks, functions, resources, technologies within the organization (internal strategic balance);

- strategic balance as a balance of organizational capabilities and strategic directions of development and opportunities and threats of the external environment, that is, external strategic balance in the industry, the sphere of doing business (external strategic balance).

The substantive characteristics of the external strategic equilibrium of an organization should be sought in scientifically grounded approaches and theories of general, economic, military-strategic equilibrium.

Summarizing the positions of famous scientists on the problem of finding equilibrium in the market, we understood that the concept of external strategic equilibrium is closely related to such categories as economic equilibrium, general equilibrium, military-strategic equilibrium, but it is not distinguished within the framework of strategic management.

Building a field of strategic priorities for the development of organizations can become a fairly effective methodological tool for determining the strategic directions of development of an organization based on an analysis of the legislative activities of the state, foreign policy and the state of the internal market, and the implementation of the identified directions (ways) of development not only in the business sector, in our case, in the telecommunications sector, but also each organization (strategic business unit) will allow to ensure a balance of the strengths and weaknesses of the organization and the opportunities and threats of the external environment, that is, they will provide external strategic balance in the industry, the sphere of doing business (external strategic balance).

Thus, the strategic balance of the organization is ensured by the achievement of internal and external strategic balance, the achievement of only one state can be considered as stability (either relative to other enterprises, or relative to the normative or planned values of various indicators of the internal development of the organization), the all-round effective strategic development of the organization presupposes the achievement of a bilateral balance external and internal balance.

Taking into account the different points of view of researchers regarding the process and models of strategic management of an organization in general and telecom operators in particular, we have developed an author's model of strategic management of organizations telecom operators (Figure 6).

The process of developing and implementing the development strategy of an organization - a telecom operator - takes place, in our opinion, in three consolidated stages: a preliminary assessment of the state of the enterprise and the impact of the external environment; formulation and choice of strategy; implementation of the strategy. This allows you to simplify the process and focus on the main directions of the organization's development.

The specificity of the model at the first stage is a broader analysis of the industry, an 
assessment of the strengths and weaknesses of the organization - a telecom operator - in the industry based on identifying the problems of the telecom operator, identifying solutions, as well as determining the strategic priorities of telecom operators, taking into account the specifics of the industry. Due to the constant changes in the external environment, aggravation of competition in the market, the indicated steps will contribute to obtaining complete, relevant, comprehensive information not only about the industry as a whole, but also about the telecom operator in particular.

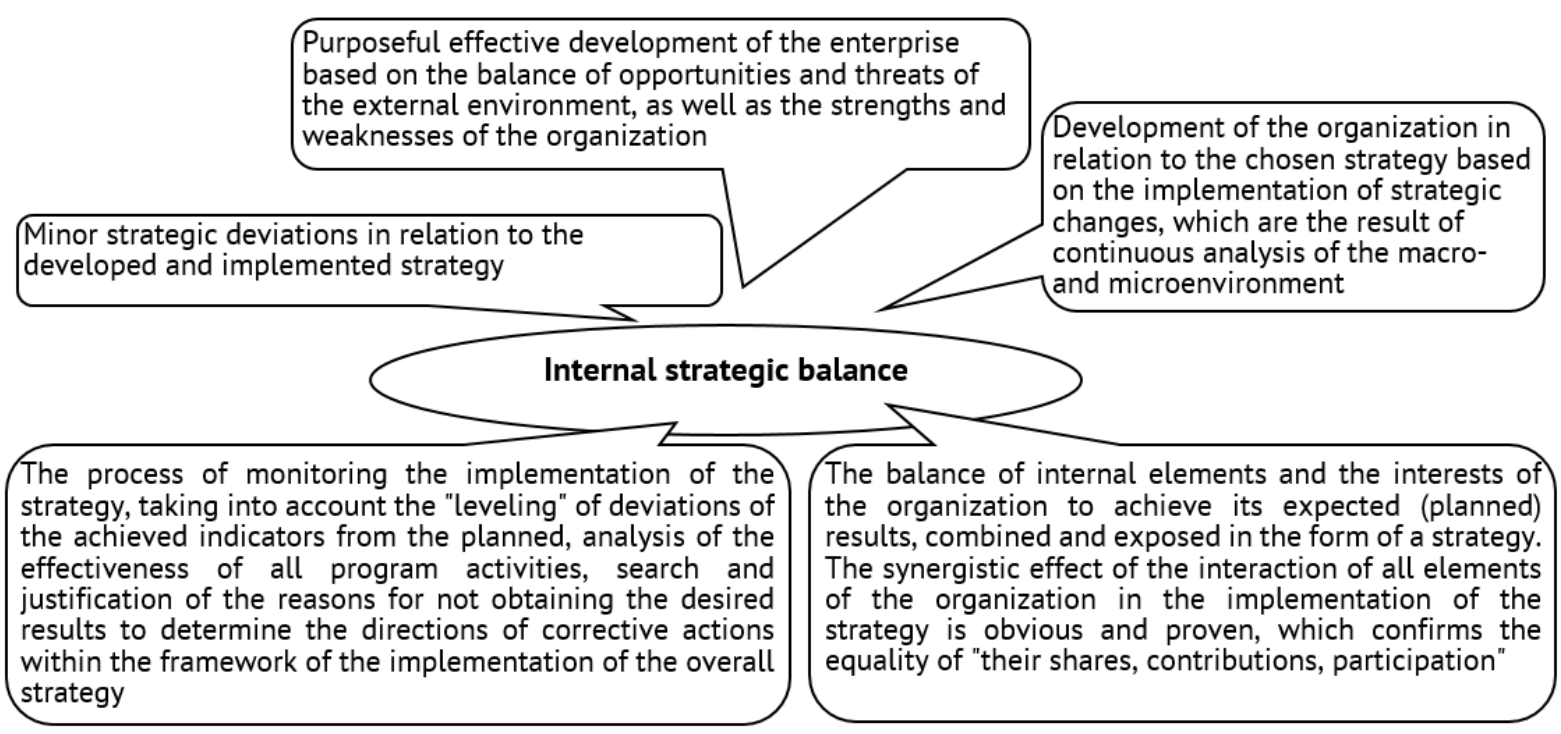

Figure 5. Substantive characteristics of the concept of internal strategic balance.

Source: compiled by the authors.

The author's addition at the second stage is the need for a better formation and selection of competitive strategies (general and specific development strategies) based on an analysis of the directions of the telecom operator's activities to ensure the strategic balance of the organization, as well as the distribution of strategies within the portfolio, the development and implementation of the priority strategic direction of the telecom operator's development within the framework of the implemented strategy.

We have identified a specific principle of strategic management - ensuring strategic balance in the organization. This stage is aimed at making the most effective choice of the organization's development strategy from the alternatives available in the portfolio, taking into account the least losses and achieving the greatest synergistic effect.

The third stage of the strategic management of organizations - telecom operators contains the specification of the target indicators of the strategy, the development of a strategic plan, the implementation of organizational changes, the analysis of the reaction to changes, the management of changes in the activities of the telecom operator, the assessment of the results of activities with the subsequent introduction of the necessary adjustments, which provides comprehensive control over the achievement of strategic development goals of telecom operators.

The developed model of strategic management of organizations - telecom operators has its own specifics, but at the same time can be adapted to any industry when carrying out the procedure of strategic management of the organization. 


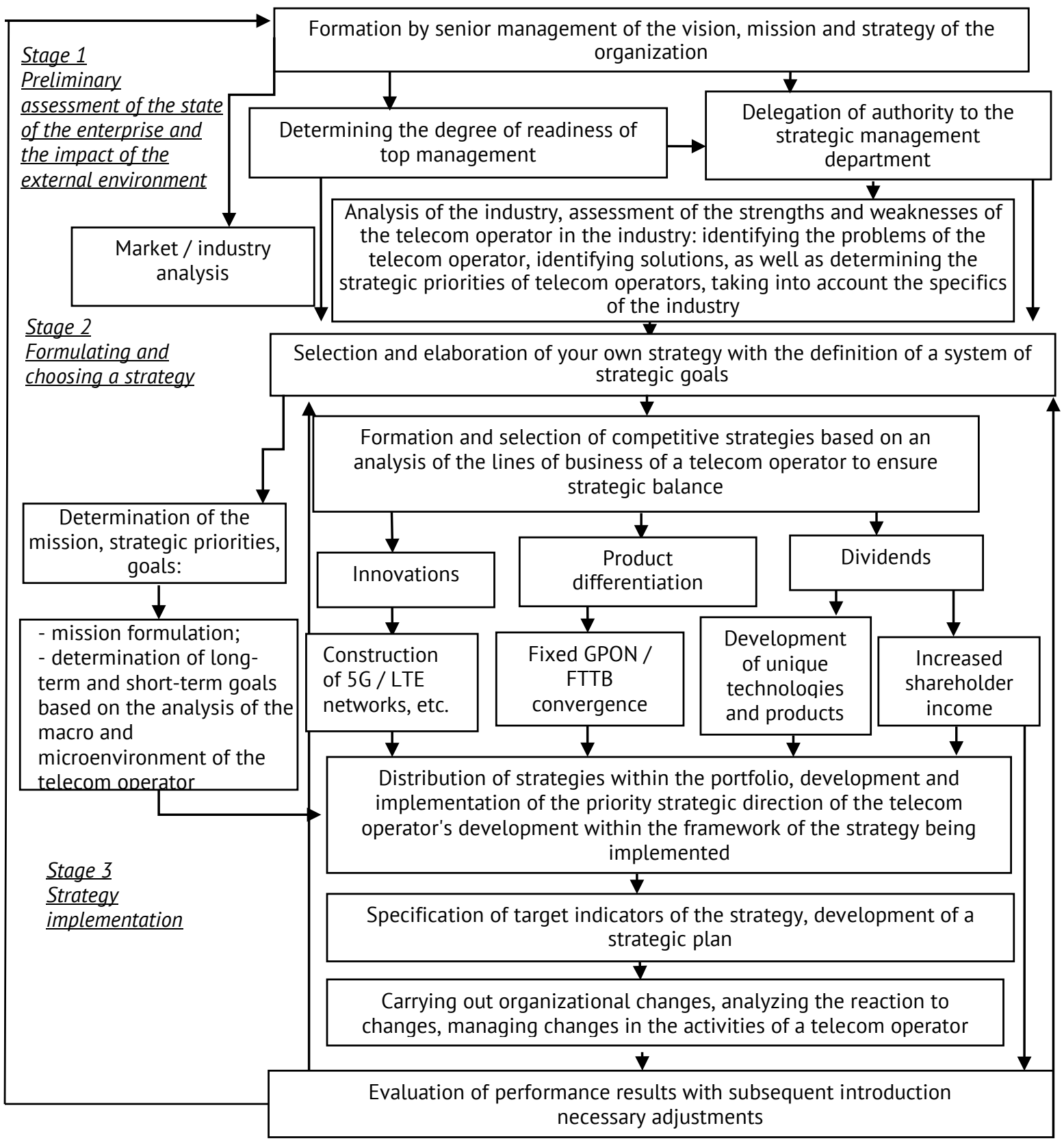

Figure 6. The author's model of strategic management of organizations - telecom operators. Source: compiled by the authors.

\section{Conclusions}

The study substantiated the need for a scientific study of the theory and practice of strategic management of organizations in the context of the digitalization of the economy, taking into account the specifics of the industry.

As a result of the study, the problem of the development of theoretical, scientific and methodological provisions, as well as practical recommendations for the strategic management of organizations in the context of the digitalization of the economy (using the examples of organizations - telecom operators) was solved, in particular, the following scientific, methodological and practical recommendations were obtained:

- the author's definition of the concept of "strategic balance of an organization" was formulated, based on an interdisciplinary approach (economic, technical, psychological, physiological, philosophical, statistical, mathematical), which differs from existing 
interpretations by highlighting two interrelated components, such as internal and external strategic balance. This makes it possible to reveal the specific features of the studied concept, which differs from such related categories as "stability", "economic equilibrium", "balance";

- the model of strategic management of organizations has been improved (on the example of telecom operators), a distinctive feature of which is to take into account the principle of strategic balance, as well as to include a block for choosing an organization's development strategy from the alternatives available in the portfolio based on minimizing losses, which will allow taking into account not only the strategic priorities of the development of organizations taking into account the specifics of the industry, but also to coordinate among themselves general and specific development strategies to ensure the strategic balance of the organization.

Acknowledgments. The study was supported by the grant of the President of the Russian Federation for state support of the leading scientific schools of the Russian Federation No. NSh-2702.2020.6 "Conceptual foundations of a new paradigm of economic development in the era of technological and social transformation"

\section{References}

1. Ackoff R. Concept of Corporate Planning. New York: Wiley, 1970.

2. Ansoff I. Strategic Management. Classic edition: Peter, 2011.

3. Chandler D. Strategy and Structure: Chapters in the History of the American Industrial Enterprise. Cambridge, MA: MIT Press, 1962.

4. David F. Strategic Management: Concepts and Cases. Prentice Hall, 2011.

5. Drucker P. Beyond the information revolution. In: Atlantic Monthly, 1999, 284 (4), pp. 42-47.

6. Fayol H. General and Industrial Management. London: Pitman, 2013.

7. Kotler F. Marketing-menedzhment. SPb.: Piter, 2006.

8. Mescon H., Albert M. \& Khedouri F. Management: Individual and Organizational Effectiveness. New York: Harper

\& Row, 1981.

9. Mintzberg H. Tracking strategies: Toward a general theory of strategy formation. New York, NY: Oxford University Press, 2009).

10. Porter M. Competitive strategy: techniques for analyzing industries and competitors: with a new introduction1 Michael E. Porter. Originallypublished: New York: Free Press, 1980.

11. Thompson A., Gamble J. and Strickland A. Strategy, core concepts, analytical tools, readings. McGraw-Hill: Irwin, 2006.

12. Emelyanov S.G., Vertakova Y.V., Kryzhanovskaya O.A., Nepochatykh O.Y. The Choice of Strategic Priorities for the Development of the Organization: A Methodological Approach. In: Lecture Notes in Networks and Systems, 2020, pp. 123-131.

13. Vertakova Y., Kryzhanovskaya O. Improving the strategic management of business communication operators. In: International multidisciplinary scientific conference on social sciences and arts: political sciences, law, finance, economics and tourism conference proceedings. Albena, Bulgaria, 2015, pp. 747-755.

14. Plotnikov V., Vertakova Y., Leontyev E. Evaluation of the effectiveness of thetelecommunication company's cluster management. In: Economic Computation and Economic Cybernetics Studies and Researchthis link is disabled, 2016, 50(4), pp. 109-118.

15. Allianz research: Digital-enabling countries proved more resilient to the Covid-19. Economic shock [online]. [accesat 03.09.2021]. Disponibil: https://www.eulerhermes.com/content/dam/onemarketing/ehndbx / eulerhermes_com/en_gl/erd/publications/the-watch/2021_02_17_Digitalresilience.pdf.

16. Newzoo Free 2021 Global Mobile Market Report [online]. [accesat 02.09.2021]. Disponibil: https://resources.newzoo.com/hubfs/Reports/Newzoo_Free_2021_Global_Mobile_Market_Report.pdf?utm_m edium=email\&_hsmi=161881863\&_hsenc=p2ANqtz-_ccgXlj55v3q0zln4vV-

mlymQqQZGbUbF_OXdydqpWoR0xmcafbfsJ1DdAVni1Scd-ETd3FfTs5OT1NrBixDOasKVyjQ\&utm_ content $=161881863 \&$ utm_source=hs_automation. 